\author{
AnNa CZAplŃSKA \\ Uniwersytet Szczeciński, Polska - University of Szczecin, Poland \\ IGOR KAVETSKYY \\ Uniwersytet Szczeciński, Polska - University of Szczecin, Poland
}

\title{
Kreowanie nowego wizerunku turystycznego jako przejaw przedsiębiorczości samorządów gmin nadmorskich
}

\section{Creating a New Tourist Image as a Manifestation of Entrepreneurship of Self-Governments of Coastal Communes (Poland)}

Streszczenie: Celem artykułu jest ocena aktywności oraz przedsiębiorczości polskich gmin nadbałtyckich w zakresie różnicowania oferty turystycznej oraz wdrażania identyfikacji wizualnej jako elementów o największym potencjale kreowania pożądanego wizerunku turystycznego obszaru. Materiał do badań stanowią podstawowe dokumenty planistyczne i materiały promocyjne 32 gmin mających bezpośredni kontakt z linią brzegową Morza Bałtyckiego. Stwierdzono, iż pozycja sektora turystycznego jako kluczowego segmentu lokalnej gospodarki jest eksponowana $\mathrm{w}$ opracowaniach strategicznych wszystkich analizowanych jednostek. Jednocześnie tylko nieliczne samorządy wykazują się właściwą pomysłowością, angażując bardziej zaawansowane instrumenty marketingowe do praktyki zarządzania własną ofertą turystyczną oraz budowania spójnego systemu identyfikacji wizualnej. Większość miast i gmin nadmorskich wciąż nie docenia charakterystycznych cech zajmowanego przez nie miejsca i opiera się na typowej ofercie wypoczynkowej oraz uniwersalnych symbolach sensorycznych związanych z nadmorską lokalizacją. Uznając oczywiste walory oraz oryginalność rozwiązań proponowanych przez liderów w tym zakresie, należy podkreślić, że w zdecydowanej większości przypadków stosowne działania znajdują się dopiero na etapie inicjacji, a ich bardziej zauważalnych efektów należy spodziewać się dopiero w przyszłości.

\begin{abstract}
The aim of the study is to assess the activity and entrepreneurship of Polish self-governments of coastal communes in the scope of diversifying the tourist offer and implementing visual identity as elements with the greatest potential to create the desired tourist image of the area. The material for research consists of basic planning documents and promotional materials of 32 communes that have direct contact with the Baltic Sea coastline. It is stated that the position of the tourism sector as a crucial segment of the local economy is exposed in the strategic studies of all analysed communes. At the same time, only a few self-governments present the proper ingenuity, engaging more advanced marketing instruments to the practice of managing their own tourist offer and building a coherent visual identity system. Most coastal cities and communes still underestimate the characteristic features of the space they occupy, based on a typical leisure offer and universal sensory symbols related to the seaside location. Recognising the obvious qualities and originality of the solutions proposed by the leaders, it should
\end{abstract}


be emphasised that in the vast majority of cases appropriate actions are only at the initiation stage, and their more noticeable effects should be expected in the future.

Słowa kluczowe: gmina nadmorska; produkt turystyczny; przedsiębiorczość jednostki samorządu terytorialnego; strategia marketingowa; system identyfikacji wizualnej; wizerunek turystyczny

Key words: coastal commune; entrepreneurship of territorial self-government unit; marketing strategy; tourist image; tourist product; visual identification system

Otrzymano: 12 listopada 2018

Received: 12 November 2018

Zaakceptowano: 22 lutego 2019

Accepted: 22 February 2019

\section{Sugerowana cytacja/Suggested citation:}

Czaplińska, A., Kavetskyy, I. (2019). Kreowanie nowego wizerunku turystycznego jako przejaw przedsiębiorczości samorządów gmin nadmorskich. Przedsiębiorczość - Edukacja [Entrepreneurship - Education], 15(1), 144-157. doi: 10.24917/20833296.151.11

\section{Wstęp}

Decentralizacja administracji publicznej w Polsce spowodowała, że na poziom gminny spadła odpowiedzialność za rozwój lokalny, którego centralnym punktem winna być przemyślana i konsekwentnie realizowana strategia rozwoju. Nieodzownym jej elementem musi być nie tylko wspieranie indywidualnej przedsiębiorczości mieszkańców (zob. Kochmańska, 2007; Pomianek, Cegiełka, 2015), ale również umiejętne zarządzanie gminą, które samo w sobie powinno nosić znamiona przedsiębiorczości, bowiem ta „stanowi podstawowy warunek rozwoju gospodarczego, społecznego i kulturowego układów przestrzennych różnej skali” (Zioło, 2007: 10). W literaturze przedmiotu pojęcie przedsiębiorczości gminy rozumiane jest jako zbiór, zestaw inicjatyw władz i mieszkańców, które zmierzają do efektywniejszego wykorzystania lub poszukiwania nowych zastosowań dla posiadanych zasobów w celu osiągnięcia przewagi konkurencyjnej jednostki, jak i samych mieszkańców (Majewska, 2006). Co warte zaznaczenia, w warunkach konkurowania o kapitał i klientów inicjatywy władz i mieszkańców powinny opierać się na „eksponowaniu tego, co specyficzne i lokalne oraz zintegrowaniu wokół wspólnego celu” (Bieńkowska, 2004: 184).

Z punktu widzenia zachodzących procesów społeczno-gospodarczych i rosnącej roli miękkich czynników lokalizacji coraz większego znaczenia nabiera kreowanie pożądanego wizerunku jednostki terytorialnej rozumianego jako wizerunek multisensoryczny, a więc wynikający z łącznego oddziaływania na wszystkie zmysły konsumenta. Zrozumienie tego mechanizmu przez władze lokalne może w krótkim czasie spowodować osiągnięcie przewagi konkurencyjnej, bowiem jednostki samorządu terytorialnego, podobnie jak przedsiębiorstwa czy organizacje, podlegają uniwersalnym regułom gry rynkowej. Jednym z ważniejszych rynków, na których trwa rywalizacja między gminami, jest rynek usług turystycznych. W sposób szczególny dotyczy to miast i gmin nadmorskich, dla których turystyka to czasem główne, jeśli nie jedyne, źródło utrzymania ich mieszkańców.

Anachroniczny i stereotypowy wizerunek polskiego wybrzeża jako strefy tradycyjnego (masowego) wypoczynku opartego na kompleksie walorów 3xS (sea, sand, sun - morze, 
piasek, słońce) nie zaspokaja wymagań wynikających z rosnącego popytu turystycznego, a jednocześnie nie przynosi oczekiwanych efektów po stronie podaży. W sytuacji, gdy interesariusze zewnętrzni stanowią bazę, a czasem wręcz warunek możliwości rozwojowych, takie postrzeganie znacząco osłabia pozycje gmin nadmorskich w aktualnym otoczeniu rynkowym. Ponadto ten spetryfikowany obraz coraz bardziej nie przystaje do rzeczywistości. Podjęte w ostatnich latach próby urozmaicenia oferty podstawowej, przede wszystkim przez intensywny rozwój aktywnych form wypoczynku, w dużej mierze zmieniły charakter polskiej turystyki nadmorskiej, której nowe oblicze wciąż jeszcze nie przełożyło się na należny wizerunek tego obszaru.

Dostrzegając ten problem, samorządy nadmorskie coraz częściej sięgają po instrumenty zarządzania marketingowego. Do praktykowanych dotychczas, często doraźnych działań promocyjnych, dochodzi coraz szersze wykorzystanie pozostałych instrumentów marketingowych, m.in. tworzenie komplementarnych pakietów produktowych dostosowanych do potrzeb i oczekiwań konkretnych grup docelowych. Nie mniej ważne jest kształtowanie właściwego odbioru społecznego przez uwypuklenie cech unikatowych i wyróżniających stosownych obszarów, utrwalenie w umysłach odbiorców ich oryginalnego wizerunku na podstawie przemyślanego systemu identyfikacji wizualnej. Dzięki wdrożeniu jednolitej i spójnej koncepcji prezentacji gminy, opartej na wyjątkowych i oryginalnych cechach danego miejsca, wyjątkowości i oryginalności nabierze zarówno oferowany produkt turystyczny, jak i cała gmina.

W związku z powyższym jako cel niniejszej pracy określono ocenę aktywności oraz przedsiębiorczości polskich gmin nadbałtyckich w zakresie różnicowania oferty turystycznej oraz wdrażania systemu identyfikacji wizualnej jako elementów o największym potencjale kreowania pożądanego wizerunku turystycznego obszaru. Materiał do badań stanowią podstawowe dokumenty planistyczne (udostępnione w gminnych Biuletynach Informacji Publicznej) i materiały promocyjne (przede wszystkim zamieszczone $\mathrm{w}$ oficjalnych serwisach internetowych) 32 gmin mających bezpośredni kontakt $\mathrm{z}$ linią brzegową Morza Bałtyckiego. Przyjmując, iż wyróżnikiem podejścia przedsiębiorczego powinno być dążenie do zapewnienia trwałej przewagi konkurencyjnej, główna uwaga została skoncentrowana na rozwiązaniach opierających się na wykorzystaniu elementów stanowiących o unikatowości, wyjątkowości, wyłączności danego miejsca. Są to bowiem walory wyróżniające jednostkę terytorialną w sposób niepodważalny i trudny do imitacji przez konkurentów, tworzące jedyny w swoim rodzaju motyw przewodni, który może zagwarantować współdziałanie całej wspólnoty lokalnej.

\section{Nadmorski produkt turystyczny i strategie jego różnicowania}

Odziedziczony po okresie gospodarki nakazowo-rozdzielczej produkt turystyczny polskich gmin nadbałtyckich, którego rdzeń stanowi regeneracja sił fizycznych, psychicznych i intelektualnych człowieka, trwał w swej niepozornej postaci (rycina 1) co najmniej do połowy lat 90. XX w. Jego fundament stanowił typowy dla obszarów nadmorskich kompleks walorów 3xS w połączeniu z podstawową infrastrukturą turystyczną związaną przede wszystkim z funkcjonującymi dotychczas zakładowymi ośrodkami wypoczynkowymi. Atrakcje dodatkowe (m.in. nieliczne obiekty krajoznawcze bądź organizowane wydarzenia) w niewielkim tylko stopniu decydowały o możliwościach urozmaicenia pobytu wypoczynkowego. W ramach tego produktu w miarę wyraźnie zaznaczają się dwa 
Rycina 1. Typowy produkt turystyczny polskich gmin nadbałtyckich w latach 90 . XX w.

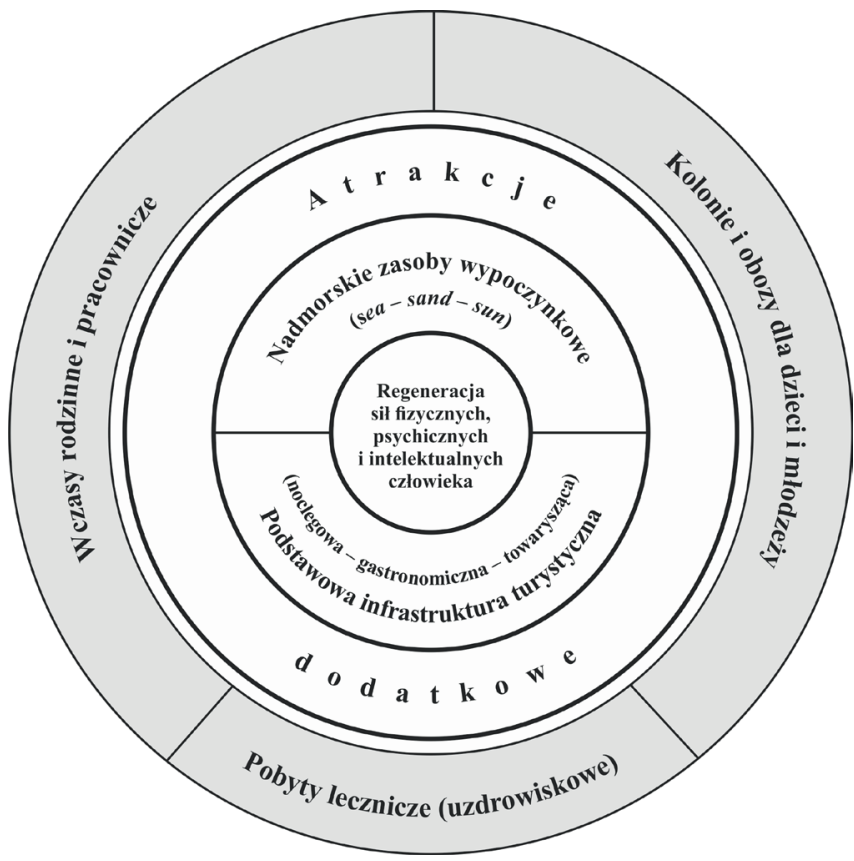

Źródło: opracowanie własne

segmenty: wczasy rodzinne i pracownicze oraz kolonie i obozy dla dzieci i młodzieży. Należy także wspomnieć o pobytach w zakładach lecznictwa uzdrowiskowego w Świnoujściu, Kołobrzegu i Ustce, prowadzących działalność opierającą się na naturalnych surowcach balneologicznych oraz walorach klimatycznych wybrzeża.

Podstawowym problemem związanym z funkcjonowaniem gospodarki turystycznej wybrzeża w oparciu o tak ukształtowany produkt okazała się być zasadnicza niezgodność między przyrodniczymi predyspozycjami obszaru a charakterem powstałego zagospodarowania (Szwichtenberg, 1991). Niska temperatura wody i słabe zasolenie Bałtyku, wysokie opady w półroczu letnim, względnie niskie temperatury powietrza, a także duża zmienność czynników pogodowych to cechy świadczące o zaledwie przeciętnych warunkach do plażowania i morskich kąpieli. Z kolei ukształtowana zgodnie z „polskim modelem turystyki socjalistycznej” struktura zainwestowania faktycznie wymuszała wypoczynek bierny. Zdecydowanie brakowało ogólnodostępnych terenów rekreacyjnych oraz infrastruktury umożliwiającej aktywne spędzanie czasu, gdyż w wielu przypadkach obiekty kubaturowe ośrodków wypoczynkowych zajmowały predysponowane do tego tereny (m.in. nadmorski bór sosnowy), nierzadko dochodząc do samej plaży. Niedocenione pozostawały właściwości hartujące klimatu nadbałtyckiego, które w połączeniu z dużym usłonecznieniem i wysokim stężeniem aerozolu morskiego tworzą niemal idealne możliwości dla szeroko rozumianej talassoterapii. Wszystko to skutkowało ogromną zależnością od nieprzewidywalnych warunków sezonowych oraz wraz z rozwojem procesów transformacji rynkowej powodowało utratę klientów na rzecz innych obszarów nadmorskich Europy. 
Rycina 2. Transformacje produktu turystycznego polskich gmin nadbałtyckich na początku XXI w.

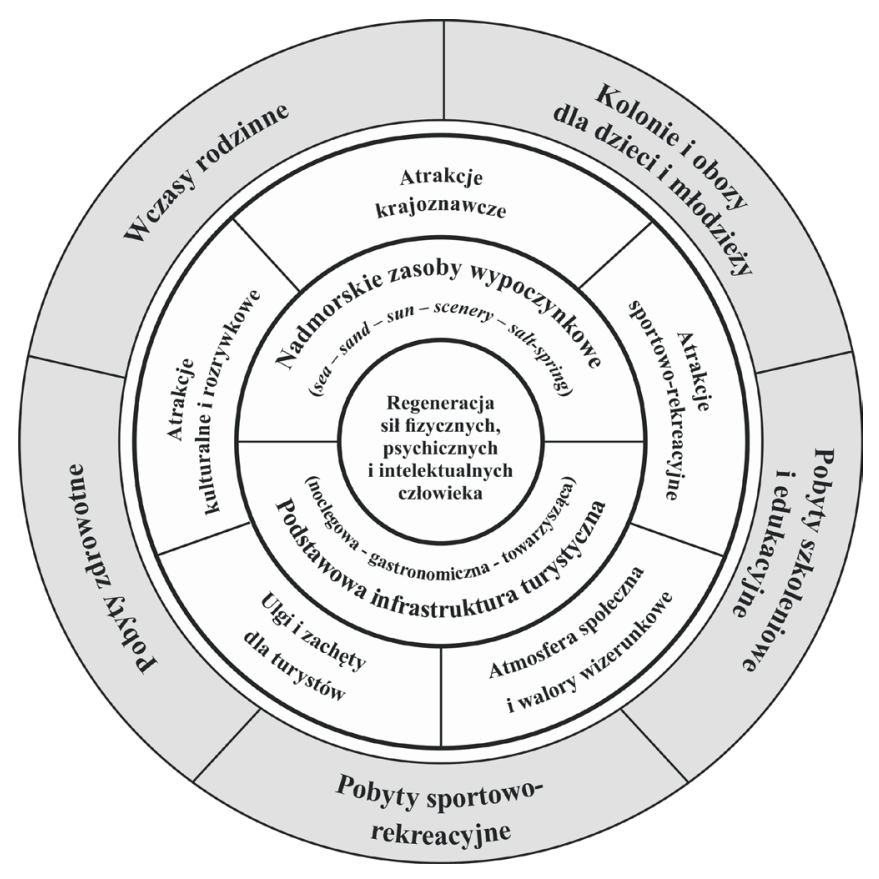

Źródło: opracowanie własne

Na przełomie XX i XXI w. nadmorski produkt turystyczny, zachowując swój dotychczasowy rdzeń, zaczął podlegać znaczącym transformacjom (rycina 2). W pierwszej kolejności na zauważenie zasługuje zmiana podstawy tego produktu polegająca na zastąpieniu dotychczasowej formuły 3xS przez bardziej odpowiednią dla obszarów nadbałtyckich, określoną przez Szwichtenberga (2006) jako 5xS, która uwzględnia dodatkowo scenery krajobraz nadmorski - oraz salt-spring - szeroko rozumiane zasoby lecznicze. W praktyce oznacza to ukierunkowanie na bardziej aktywne formy wypoczynku oraz szersze wykorzystanie właściwości zdrowotnych klimatu nadmorskiego. Zasadniczej modernizacji poddana zostaje infrastruktura turystyczna wybrzeża. Znaczącemu wzbogaceniu ulegają elementy poszerzające ofertę podstawową. Wśród tych ostatnich warto wyodrębnić kilka osobnych kategorii zdecydowanie uatrakcyjniających nadmorski produkt wypoczynkowy oraz dopasowujących go do preferencji różnych grup turystów, m.in. wielorakie atrakcje krajoznawcze, atrakcje kulturalne i rozrywkowe, atrakcje sportowo-rekreacyjne. Oddzielnie należy wymienić różnego rodzaju ulgi i zachęty dla turystów (np. karta turystyczna) czy walory wizerunkowe (np. rozpoznawalna marka).

Poszerzeniu ulega segmentacja produktu. Zachowują swoje znaczenie dotychczas istniejące pobyty wczasowe i kolonijne, ale znaczącemu przekształceniu ulega segment uzdrowiskowy przez upowszechnienie się oferty pobytów nie tyle leczniczych, ile zdrowotnych (niezależnych od oficjalnego statusu uzdrowiska, który dodatkowo uzyskały Dąbki w gminie Darłowo oraz Sopot), opierających się na rozwoju alternatywnych całorocznych usług typu spa\&wellness. Najbardziej imponującą zmianą jest oferta pobytów 
sportowo-rekreacyjnych, często również o charakterze całorocznym, związanych z propozycją form aktywnego spędzania czasu, m.in.: turystyka rowerowa i piesza, jeździectwo, paralotniarstwo, motolotniarstwo i loty widokowe, żeglarstwo i sporty motorowodne, windsurfing i kitesurfing, rejsy wycieczkowe i wędkarskie. Stopniowo klaruje się także segment związany z ofertą szkoleniową i edukacyjną obejmujący propozycje organizacji szkoleń i konferencji, spotkań biznesowych oraz imprez motywacyjnych, wycieczek przyrodniczych i krajoznawczych itp. Kwestią niejednoznaczną jest rozstrzygnięcie, czy wyodrębnione powyżej segmenty należy wciąż rozpatrywać w ramach jedynego nadmorskiego produktu wypoczynkowego, czy są to już poniekąd samodzielne produkty turystyczne.

O skali zarysowanych powyżej transformacji świadczą przede wszystkim treści oficjalnych serwisów internetowych poszczególnych miast i gmin nadbałtyckich. O ile w okresie wcześniejszym informacje dla turystów zwykle ograniczały się do ogólnej prezentacji walorów turystycznych oraz kalendarza imprez, o tyle obecnie odpowiednia pozycja menu obowiązkowo zawiera nawet kilka podstron związanych z ofertą aktywnego wypoczynku oraz innymi elementami uatrakcyjniającymi pobyt w regionie. Upowszechnienie koncepcji turystyki nadmorskiej opartej na modelu 5xS jest w dużej mierze uwarunkowane nowymi realiami funkcjonowania samorządów oraz ich coraz większym zaangażowaniem jako pełnoprawnych uczestników rynku. To właśnie „postępująca konkurencja pomiędzy jednostkami terytorialnymi, rozumiana nie tylko jako konkurowanie między przedsiębiorstwami w regionach, ale także jako konkurowanie kompleksowych obszarów terytorialnych" (Florek, 2007: 7) może być uznana za jeden z ważniejszych powodów wymuszających wzbogacenie podstawowego produktu turystycznego o nowoczesne formy aktywności, co jest traktowane m.in. jako sposób na odróżnienie się od innych gmin wybrzeża. Wydaje się, że stosowne poczynania, przynajmniej początkowo, sprzyjały umocnieniu pozycji konkurencyjnej liderów w tym zakresie, jednak niebawem, wobec powszechności dokonywanych transformacji, doprowadziły - poniekąd paradoksalnie do ponownego upodobnienia się jednostek strefy nadmorskiej, aczkolwiek na jakościowo wyższym poziomie w stosunku do sytuacji z początku lat 90. XX w.

Aktualnie miasta i gminy nadbałtyckie stają więc przed kolejnym wyzwaniem oraz aktywnie poszukują optymalnej drogi w zmieniającej się rzeczywistości rynkowej. Świadectwem tego są specjalistyczne opracowania planistyczne dotyczące rozwoju sektora turystyki i rekreacji, opierające się na szeroko zakrojonym audycie turystycznym, często przygotowywane na zamówienie przez wyspecjalizowane agencje marketingowe. Na szczególną uwagę wydają się zasługiwać te spomiędzy nich, które zakładają odejście od orientacji jednoproduktowej na rzecz różnicowania oferty turystycznej przez wytypowanie turystycznych produktów markowych (ewentualnie wiodących i uzupełniających), niekiedy z uwzględnieniem dodatkowych propozycji jednodniowych, weekendowych czy tygodniowych. Cechami wyróżniającymi takie produkty są obowiązkowe elementy kreatywne oraz interaktywne, aktywizujące i angażujące turystów, pozwalające na zdobywanie wiedzy i nowych doświadczeń w połączeniu z odczuwaniem głębokich emocji i satysfakcji. Należy przyjąć, że takie podejście w najwyższej mierze odzwierciedla ideę turystyki przyszłości określanej mianem 3xE (entertainment, excitement, education - rozrywka, ekscytacja, edukacja) (Alezjak, 1999) lub niekiedy 4xE, dodając odpowiednio engagement - zaangażowanie (Połucha, Žukovskis, 2015). Mimo że podwaliny wspomnianej idei da się już dostrzec w realizowanym przez samorządy nadmorskie modelu turystyki 
Rycina 3. Model organizacji oferty turystycznej miejsca zgodnie z ideą 3xE

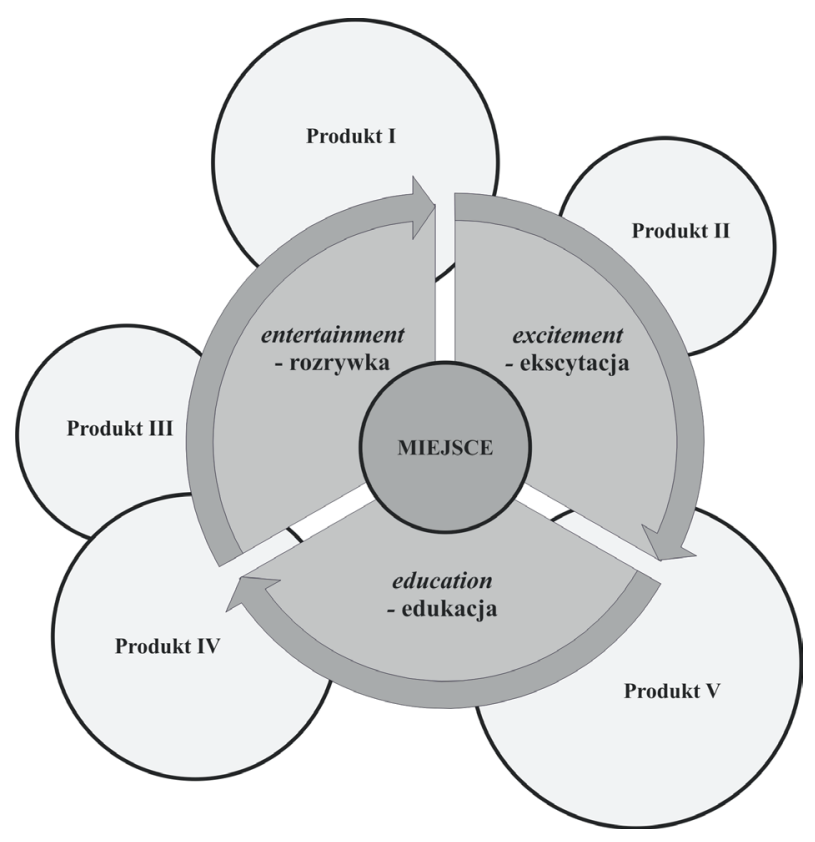

Źródło: opracowanie własne

Rycina 4. Turystyka w opracowaniach planistycznych polskich gmin nadbałtyckich

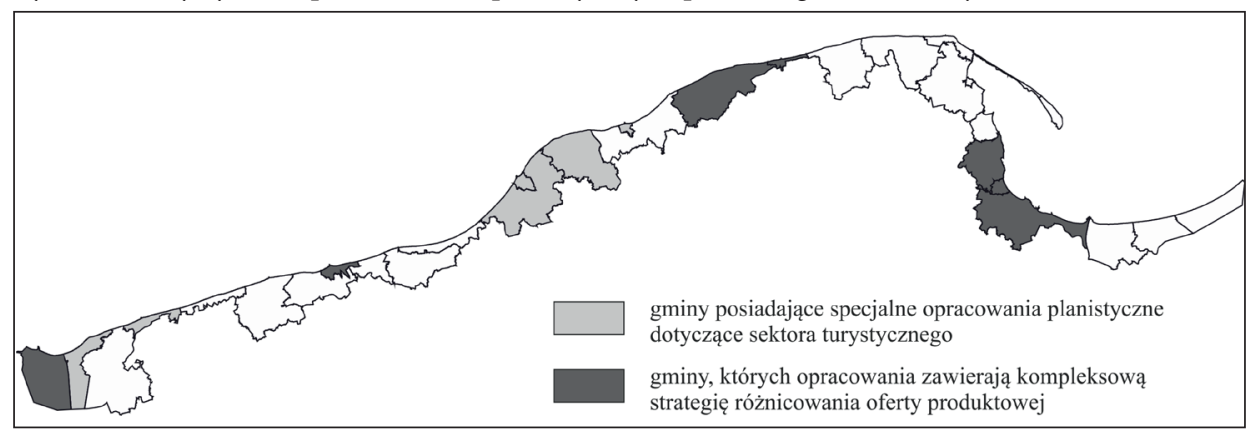

Źródło: opracowanie własne

5xS, to wydaje się, że jej maksymalne spełnienie możliwe będzie w ramach komplementarnych pakietów produktowych dostosowanych do potrzeb i oczekiwań konkretnych grup docelowych oraz opartych na specyfice i osobliwościach danego miejsca (rycina 3). Ten ostatni aspekt tworzy ponadto dla jednostek samorządowych niepowtarzalną szansę na zajęcie unikatowej pozycji rynkowej wobec trudności lub wręcz niemożności powielenia wprowadzonych rozwiązań przez konkurencję.

Wracając do rzeczywistości polskich gmin nadbałtyckich, należy zaznaczyć, że pozycja sektora turystycznego jako kluczowego segmentu lokalnej gospodarki jest eksponowana $\mathrm{w}$ opracowaniach strategicznych wszystkich omawianych jednostek. Jednak jakiekolwiek opracowanie o charakterze planistycznym (strategia, program lub 
przynajmniej plan działań) odnoszące się stricte do sektora turystycznego ma jedynie 13 z 32 (40,6\%) gmin mających bezpośredni kontakt z linią brzegową. Z kolei zaledwie w przypadku 7 gmin (Świnoujście, Kołobrzeg, Smołdzino, Łeba, Gdynia, Sopot oraz Gdańsk) stosowne opracowania zawierają kompleksową strategię różnicowania oferty produktowej (rycina 4).

Za dobry przykład stopniowo wdrażanej strategii różnicowania oferty turystycznej można uznać Świnoujście. Miasto to jako pierwsze spomiędzy polskich gmin nadbałtyckich już w 2002 r. zainicjowało specjalny program, opracowany przez Polską Agencję Rozwoju Turystyki SA (Program rozwoju..., 2002), ukierunkowany na realizację przyszłościowej wizji „kurortu na wyspach” z niecodziennymi atrakcjami turystycznymi wynikającymi ze szczególnego położenia geograficznego, różnorodności przyrodniczej i dziedzictwa kulturowego. Centralne miejsce w tym programie zajmuje koncepcja zintegrowanego produktu turystycznego, w ramach której wskazano cztery produkty o charakterze strategicznym (turystyka uzdrowiskowo-zdrowotna, turystyka wypoczynkowo-rodzinna, turystyka kulturowo-miejska oraz turystyka aktywna i kwalifikowana) stanowiące o profilu turystycznym miasta, jego przyszłym wizerunku oraz wymiernym efekcie ekonomiczno-rynkowym. Zgodnie z zasadą integralności założono wzajemne wspomaganie i uzupełnianie się elementów współtworzących poszczególne produkty oraz przenikanie się segmentów turystów w nawiązaniu do ich specyficznych zainteresowań. Dodatkowo określono 7 produktów uzupełniających (m.in. turystyka ekologiczna, turystyka biznesowa, turystyka przygraniczna itp.), mających zagwarantować zmniejszenie potencjalnego ryzyka ukrytego w zmieniających się trendach i potrzebach rynku turystycznego.

W chwili obecnej opracowywana jest marketingowa strategia rozwoju turystyki i kreacji marki miasta jako jedno z zadań do programu „Świnoujście kurortem całorocznym” w ramach Wieloletnich Strategicznych Programów Operacyjnych Miasta Świnoujście na lata 2014-2020 (2014). Sądząc z zapisów programu, powstająca strategia będzie właściwą kontynuacją oraz rozwinięciem idei z 2002 r., uwzględniającą jednak najnowsze tendencje w oczekiwaniach klientów, m.in. rozszerzenie oferty turystycznej w oparciu o walory przyrodnicze, wartości historyczne i transgraniczność miasta. W strategii zapewne pojawią się marketingowe nazwy oferowanych produktów turystycznych, z których przynajmniej część de facto już zaistniała na oficjalnej stronie miasta (Kraina 44 wysp, 2018): „Wyspy zdrowia i urody”, „Twierdza na wyspach”, „Aktywnie na wyspach”, „Wyspy dla najmłodszych". Jak łatwo zauważyć, używane nazwy bezpośrednio nawiązują do najbardziej charakterystycznej osobliwości Świnoujścia i są gwarancją unikatowości oferty.

Strategie różnicowania oferty produktowej sześciu innych samorządów nadmorskich tworzone są na podobnych zasadach i zawierają oryginalne rozwiązania opierające się na specyfice odpowiednich miejsc. Należy jednak podkreślić, że, w odróżnieniu od Świnoujścia, stosowne pomysły nie znajdują należnego odzwierciedlenia w materiałach promocyjnych lub są przedstawione w sposób nader skromny. Analiza tych materiałów pozwala wręcz twierdzić o dużej przepaści pomiędzy perspektywicznymi wizjami konkurencyjnej oferty produktowej a informacjami dostarczanymi ich potencjalnym konsumentom.

\section{System identyfikacji wizualnej}

Wzrost konkurencji w strefie nadmorskiej oraz mało zróżnicowana oferta turystyczna wymagają nie tylko dywersyfikacji produktu turystycznego w poszczególnych gminach, 
ale również poszukiwania nowych sposobów dla wyróżnienia się na rynku. W ramach działań marketingowych, które ukierunkowują potrzeby nabywców, wywierają wpływ na ich postawy i zachowania, a więc odgrywają niebagatelną rolę w budowaniu świadomości marki, jednostki samorządu terytorialnego często koncentrują się na marketingu bezpośrednim, reklamie, działaniach public relations, których cechą wspólną jest pulsacyjne oddziaływanie na rynki docelowe, o charakterze doraźnym, zależnym od wielkości dostępnego budżetu. Istnieje jednak instrument oddziaływujący na rynek w sposób permanentny, trwale wyróżniający daną jednostkę terytorialną, zapewniający nieustanne przekazywanie informacji. Jest to identyfikacja wizualna rozumiana jako zbiór wzorców i reguł, których zadaniem jest konsekwentne tworzenie pozytywnych wyobrażeń o jednostce oraz utrwalenie ich w opinii odbiorców (Altkorn, Kramer, 1998).

Nawiązując do idei Jurowskiego (2004), system jednolitej identyfikacji wizualnej musi opierać się na najbardziej charakterystycznych elementach jednostki terytorialnej (znak, kolorystyka), które będą stosowane w różnych nośnikach i będą wzbudzać zaufanie wśród odbiorców. Czytelność i atrakcyjność elementów tożsamości wizualnej przekłada się na efekty akcji promocyjno-reklamowych, które w sposób bezpośredni kształtują wizerunek jednostki samorządu terytorialnego. System identyfikacji wizualnej ma na celu przede wszystkim zwrócenie uwagi i wywołanie zainteresowania. Musi więc wyróżniać daną jednostkę spośród innych, motywować i przekonywać odbiorcę, aby wiązać go z gminą. Identyfikacja wizualna powinna odpowiadać lokalnej specyfice, zachowywać zgodność z całym systemem komunikacji rynkowej, będąc jednocześnie komponentem oryginalnym i zauważalnym, łatwym w percepcji i zapamiętywaniu (Dmitruk, 2010). Dlatego tak ważne jest staranne przemyślenie i opracowanie systemu identyfikacji wizualnej z myślą o długotrwałości jego działania. Zwykle na system identyfikacji wizualnej jednostki samorządu terytorialnego składają się: symbol (logo, logotyp), przyjęta kolorystyka i grafika, ujednolicona stylistyka materiałów promocyjnych i reklamowych, zunifikowany wygląd najważniejszych miejsc użyteczności publicznej, np. przystanków komunikacji miejskiej, itp.

Podstawowym i najczęściej ocenianym elementem marketingowego zarządzania wizerunkiem jest logo lub logotyp - znak graficzny jednoznacznie identyfikujący, w tym przypadku jednostkę samorządu terytorialnego. Według Kotlera (1994: 280) „silny image uzyskuje się w wyniku stosowania jednego lub kilku symboli odzwierciedlających pozycję przedsiębiorstwa lub marki”. W kreowaniu pożądanego wizerunku jednostki samorządowej logo, niezależnie od miejsca i materiału, na którym się pojawi, powinno pełnić funkcję dopełnienia, weryfikacji, klasyfikowania i hierarchizowania w umysłach ludzkich informacji dotyczących tej jednostki. Dlatego musi być odpowiednio zaprojektowane i spełniać kilka uzupełniających się i równoważnych funkcji (Macalik, 2013):

- przyciągać uwagę, np. grafiką i kolorystyką,

- poszerzać wiedzę o jednostce terytorialnej, np. akcentując jej nazwę, położenie itp.,

- wyróżniać daną jednostkę wśród innych (sąsiadujących, konkurencyjnych, np. innych gmin nadmorskich),

- gwarantować powiązanie jednostki samorządowej z oferowanymi zasobami, produktami lub własną marką, poświadczając tym samym jej oryginalność,

- wywoływać pozytywne emocję.

Przyjmując za punkt wyjścia powyższe rozważania, można stwierdzić, że w chwili obecnej żadna z polskich gmin nadbałtyckich nie spełnia wszystkich wymagań stawianych 
Rycina 5. Opracowanie systemu identyfikacji wizualnej w polskich gminach nadbałtyckich

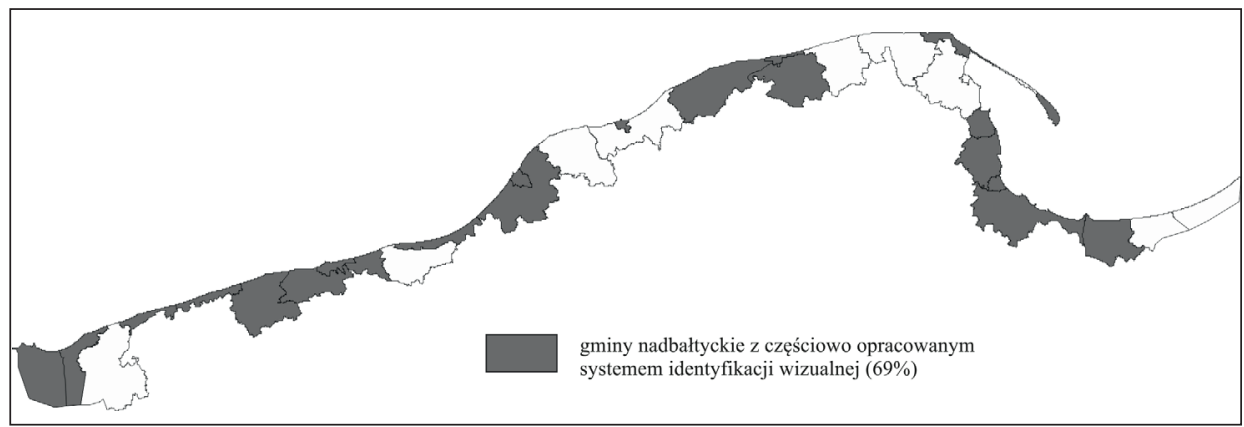

Źródło: opracowanie własne

do identyfikacji wizualnej. Zresztą trudno znaleźć taką jednostkę w całym regionie nadmorskim. Według autorskich ustaleń, zaledwie 29,8\% gmin województwa zachodnio-pomorskiego oraz 36,3\% województwa pomorskiego posiada częściowo opracowany system identyfikacji wizualnej. Pod częściowym opracowaniem należy rozumieć posiadanie jako minimum logo (logotypu), w tym logo z wykorzystaniem motywów herbowych oraz wykorzystanie kolorystyki z logo na oficjalnych stronach internetowych. W przypadku gmin bezpośrednio sąsiadujących z Bałtykiem wskaźnik ten jest zdecydowanie wyższy, gdyż taki system posiada 22 z 32 (68,8\%) badanych jednostek (rycina 5).

Spomiędzy wszystkich funkcji spełnianych przez właściwie zaprojektowane logo do najczęściej występujących w przypadku gmin nadbałtyckich można zaliczyć tylko przyciąganie uwagi oraz wywoływanie pozytywnych emocji. Przytłaczająca większość używanych elementów nie niesie ze sobą żadnej informacji szczegółowej, wyróżniającej, oryginalnej. Zwykle wykorzystywane są uniwersalne symbole pasujące do niemal każdej miejscowości nadmorskiej na świecie, takie jak: słońce, żagle, fale, mewy, latarnie itp. (rycina 6). Można przytoczyć kilka okoliczności, w jakiejś mierze usprawiedliwiających zaznaczone mankamenty. Jedną z nich jest zapewne problem trafnego wyboru informacji graficznej w sytuacji niedoprecyzowania właściwych cech tożsamości gminy, które miałyby stać się podstawą kreowania jej pożądanego wizerunku. Inną, nie mniej ważną okolicznością, jest zróżnicowany adresat przekazu. Należy bowiem pamiętać, że grupa docelowa może składać się z mieszkańców, inwestorów, turystów i osób odwiedzających (w dodatku polskich i zagranicznych), studentów itp. Nie bez znaczenia wydaje się być też trwała jednoznaczność przekazu, o którą czasem trudno z uwagi na różnice kulturowe lub pokoleniowe. Wreszcie istotny pozostaje odpowiednio długi czas konsekwentnego wykorzystywania tego samego przekazu bez jakichkolwiek modyfikacji. Zbyt częsta zmiana identyfikacji graficznej wpływa niekorzystnie na jej odbiór. Dlatego należy podkreślić, że opracowanie logo lub logotypu jest zadaniem złożonym i wiąże się z dużą odpowiedzialnością. Stąd podczas jego tworzenia istnieje potrzeba otwartej dyskusji publicznej, która winna się toczyć pomiędzy wszystkimi zainteresowanymi. W przeciwnym wypadku, czując się pominięci w tym procesie, mogą oni mieć duże problemy z akceptacją jego efektów.

Wśród pozytywnych, choć nielicznych, przykładów gmin z dobrze skonstruowanym logotypem należy przywołać przede wszystkim Świnoujście i Smołdzino (rycina 7). Wspomniane logotypy przedstawiają najważniejsze elementy wizerunkowe tych jednostek w sposób pozytywny, zauważalny, oryginalny i atrakcyjny. Gmina Świnoujście 
Rycina 6. Przykłady logotypów polskich gmin nadbałtyckich niespełniających wszystkich wymagań wg Macalik (2013)
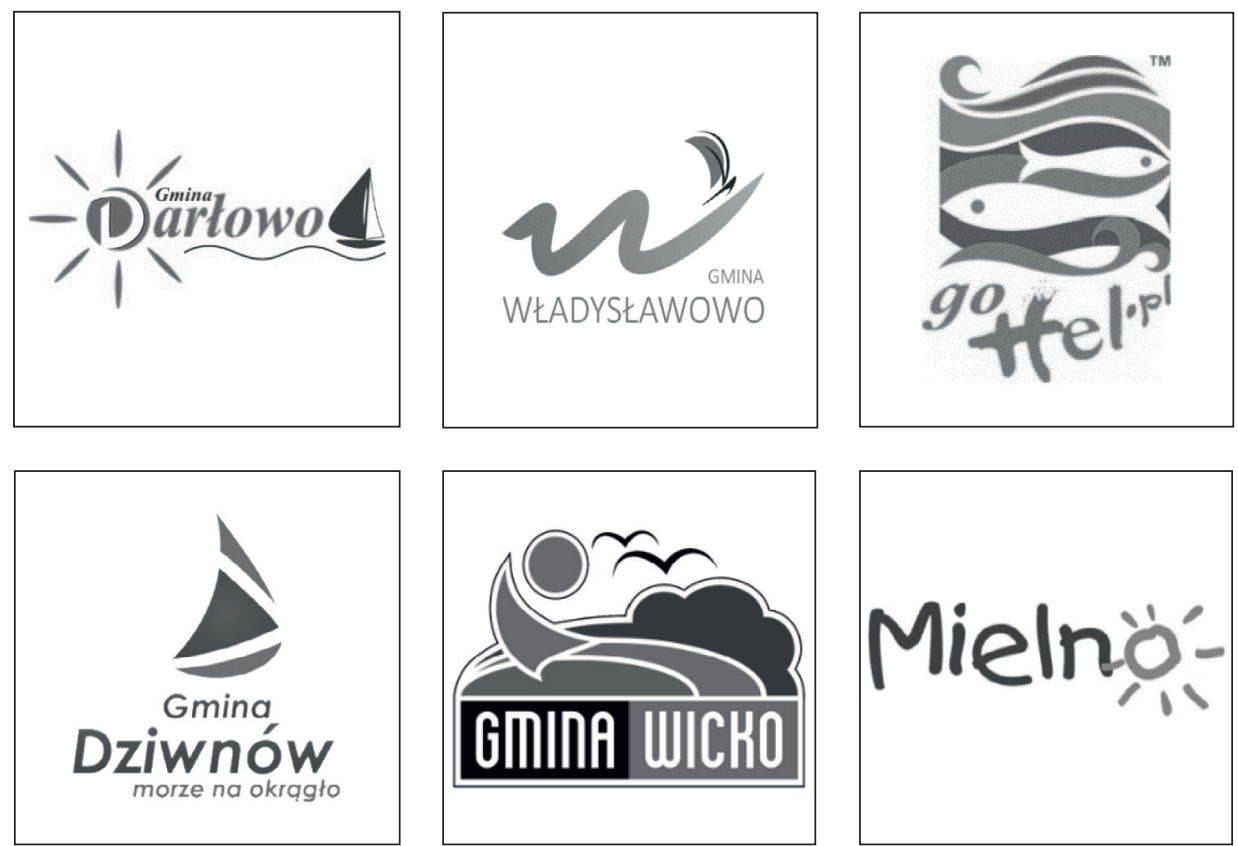

Źródło: logotypy z oficjalnych stron internetowych gmin

Rycina 7. Pozytywne przykłady logotypów polskich gmin nadbałtyckich
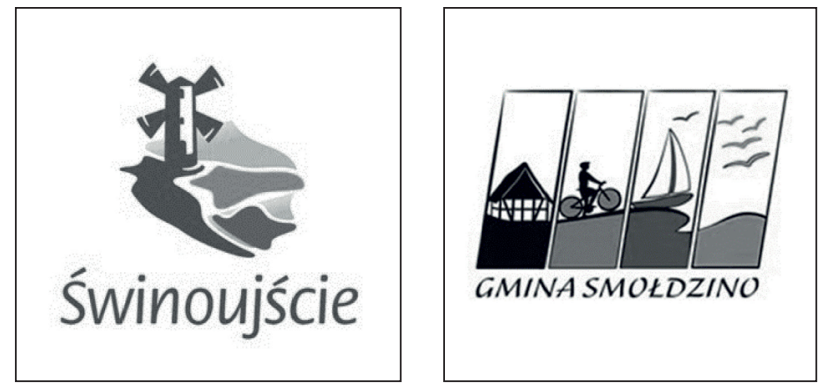

Źródło: logotypy z oficjalnych stron internetowych gmin

wykorzystuje element graficzny wysp, promując siebie pod hasłem „Kurort na wyspach” lub „Kraina 44 wysp”, oraz uwidacznia jeden z najbardziej rozpoznawalnych obiektów stawę w kształcie wiatraka (Stawa Młyny), z którą utożsamia się miasto. Z kolei Smołdzino w swoim logotypie eksponuje cztery wiodące markowe produkty turystyczne („W poszukiwaniu kultury Słowińców”, „Rowerem nad Bałtyk”, „Aktywne wakacje” i „Ptasi raj”), podkreślając w ten sposób największe zalety gminy. Oba logotypy spełniają wszystkie wymagania stawiane tego typu znakom graficznym, a dodatkowo ilustrują wprowadzane $\mathrm{w}$ tych gminach różnicowanie oferty turystycznej. Można więc uznać, że są to liderzy $\mathrm{w}$ promowaniu nowego modelu organizacji oferty turystycznej miejsca. 


\section{Zakończenie}

Przeprowadzone badania pozwalają poczynić kilka zasadniczych uogólnień. Przede wszystkim należy podkreślić powszechne przekonanie o doniosłej roli sektora turystycznego jako kluczowego segmentu lokalnej gospodarki oraz towarzyszącą temu świadomość istotnych ograniczeń, które niesie w sobie odziedziczony po poprzednich pokoleniach model uprawiania turystyki na polskim wybrzeżu. W tym kontekście jak najbardziej słuszne są dążenia władz samorządowych do wprowadzenia niezbędnych zmian, służących w pierwszej kolejności złagodzeniu wahań sezonowych w kształtowaniu się ruchu turystycznego oraz zwiększeniu konkurencyjności oferty pobytów nadmorskich. Niezrozumiały wydaje się jednak fakt braku specjalistycznych opracowań planistycznych dotyczących tego sektora, co uniemożliwia lub przynajmniej znacząco utrudnia prowadzenie długofalowej polityki w tym zakresie.

Jednoznacznie pozytywnie należy ocenić zasadniczy zwrot w praktyce zarządzania terytorialnego w kierunku coraz szerszej implementacji instrumentów marketingowych. Kluczowe miejsce w tym zakresie zajmują działania związane z kreowaniem komplementarnych pakietów produktowych dostosowanych do potrzeb i oczekiwań konkretnych grup docelowych oraz z wdrożeniem jednolitych systemów identyfikacji wizualnej, które w sposób permanentny będą wspomagać kreowanie pożądanego wizerunku miast i gmin nadbałtyckich. Liderzy w stosowaniu takich rozwiązań to przede wszystkim największe ośrodki miejskie wybrzeża, mające znaczne doświadczenie, kontakty biznesowe i zasobne budżety na realizację stosownych działań. Pomaga im również utrwalona pozycja na mapie mentalnej polskiego wybrzeża. Zapewne istotną barierą w rozpowszechnieniu się podobnych wzorów są ograniczone środki finansowe znajdujące się w dyspozycji poszczególnych samorządów, zwłaszcza mniejszych jednostek. Warto jednak postawić również pytanie, czy gminy dysponują odpowiednimi zasobami ludzkimi, które są w stanie sprostać takim zadaniom?

Większość gmin nadmorskich niestety nie docenia charakterystycznych oraz wyróżniających cech zajmowanego przez nie miejsca, opierając się na typowej (aczkolwiek zmodyfikowanej w ostatnim okresie) ofercie wypoczynkowej oraz uniwersalnych symbolach wizualizacyjnych, co prawda związanych z nadmorską lokalizacją, ale pasujących do niemal każdej takiej miejscowości na świecie. Istniejące pozytywne przykłady w tym zakresie, choć nieliczne w chwili obecnej, powinno się postrzegać jako przejawy prawdziwej przedsiębiorczości, kreatywności i innowacyjności samorządów gminnych oraz sumienności w wypełnianiu nałożonych na nie funkcji. Rozwiązania, których podwaliny są ugruntowane w lokalnej specyfice i osobliwościach konkretnych miejsc, są bowiem gwarancją skutecznego pozycjonowania oraz uzyskania długotrwałej przewagi konkurencyjnej wobec trudności, czy wręcz niemożności ich powielenia przez inne jednostki terytorialne. Na koniec warto zauważyć, iż mimo niezaprzeczalnych walorów oraz oryginalności powstających projektów, w zdecydowanej większości przypadków znajdują się one dopiero na etapie inicjacji, a ich bardziej zauważalnych efektów należy spodziewać się dopiero w przyszłości. 


\section{Literatura}

References

Alezjak, W. (1999). Turystyka w obliczu wyzwań XXI wieku. Kraków: F.H-U. Albis.

Altkorn, J., Kramer, T. (1998). Leksykon marketingu. Warszawa: Polskie Wydawnictwo Ekonomiczne.

Bieńkowska, B. (2004). Lokalne uwarunkowania rozwoju przedsiębiorczości. W: J. Brdulak, M. Kulikowski (red.), Przedsiębiorczość stymulatorem rozwoju gospodarczego. Warszawa: Instytut Wiedzy.

Dmitruk, J. (2010). System Identyfikacji Wizualnej jako narzędzie budowania wizerunku jednostki samorządu terytorialnego na przykładzie województwa mazowieckiego. W: K. Krzyżanowska (red.), Wizerunek jednostek samorzadu terytorialnego. Warszawa: SGGW.

Florek, M. (2007). Podstawy marketingu terytorialnego. Poznań: Akademia Ekonomiczna w Poznaniu.

Jurowski, M. (2004). Jednolita identyfikacja wizualna. Biuletyn EBIB, 5(56). Pozyskano z: http://www. ebib.pl/2004/56/jurowski.php

Kochmańska, M. (2007). Działalność gminy w zakresie rozwoju przedsiębiorczości lokalnej. Przedsiębiorczość - Edukacja, 3, 61-70.

Kotler, P. (1994). Marketing. Analiza, planowanie, wdrażanie i kontrola. Warszawa: Gebethner i S-ka.

Kraina 44 wysp (2018, 1 października). Pozyskano z: http://www.swinoujscie.pl/pl/contents/content/227/2345http://www.swinoujscie.pl/pl/contents/content/227/2345.

Macalik, J. (2013). Logotyp jako podstawowy element identyfikacji wizualnej miasta - wybrane problemy. Zeszyty Naukowe Wyższej Szkoły Bankowej we Wrocławiu, 1(33), 147-161.

Majewska, J. (2006). Wyzwalanie ducha przedsiębiorczości w środowisku społecznym gminy dla rozwoju lokalnego. Przedsiębiorczość - Edukacja, 2, 91-100.

Połucha, I. Žukovskis, J. (2015). Interakcje w przestrzeni: nowe trendy w animacji turystyki. Ekonomiczne Problemy Turystyki, 1(29), 73-83.

Pomianek, I., Cegiełka, M. (2015). Wydatki inwestycyjne jednostek samorządu terytorialnego jako instrument wspierania przedsiębiorczości - przykład gminy Stanisławów. Zeszyty Naukowe Wyższej Szkoły Ekonomiczno-Społecznej w Ostrołęce, 18, 36-51.

Program rozwoju produktu turystycznego oraz kreacji marki miasta Świnoujście (2002). Warszawa: Polska Agencja Rozwoju Turystyki SA. Pozyskano z: http://bip.um.swinoujscie.pl/attachments/ download/45553

Szwichtenberg, A. (1991). Stymulatory i bariery rozwoju funkcji turystycznej w polskiej strefie nadbałtyckiej. Koszalin: Wojewódzka i Miejska Biblioteka Publiczna w Koszalinie.

Szwichtenberg, A. (2006). Gospodarka turystyczna polskiego wybrzeża. Koszalin: Wydawnictwo Politechniki Koszalińskiej.

Wieloletnie Strategiczne Programy Operacyjne Miasta Świnoujście na lata 2014-2020 (2014). Świnoujście: Urząd Miasta Świnoujście. Pozyskano z: http://bip.um.swinoujscie.pl/attachments/download $/ 45554$

Zioło, Z. (2007). Rola przedsiębiorczości w aktywizacji gospodarczej - zarys modelu. Przedsiębiorczość Edukacja, 3, 10-17.

Anna Czaplińska, dr, adiunkt, Uniwersytet Szczeciński, Wydział Nauk o Ziemi, Instytut Geografii Społeczno-Ekonomicznej i Gospodarki Przestrzennej, Zakład Geografii Społecznej i Organizacji Przestrzeni. Jej zainteresowania badawcze są związane z problematyką geografii społecznej i kulturowej, w tym z krajobrazem kulturowym, procesami akulturacji oraz kulturowymi uwarunkowaniami kreowania marketingu terytorialnego.

Anna Czaplińska, PhD, associate professor, University of Szczecin, Faculty of Geosciences, Institute of Socio-Economic Geography and Spatial Management, Human Geography and Spatial Organization Unit. Research interests related to the issues of social and cultural geography, including the cultural landscape, the processes of acculturation and the cultural determinants of creating territorial marketing.

ORCID: 0000-0002-6294-5101 


\section{Adres/Address:}

Uniwersytet Szczeciński

Wydział Nauk o Ziemi

Instytut Geografii Społeczno-Ekonomicznej i Gospodarki Przestrzennej

Zakład Geografii Społecznej i Organizacji Przestrzeni

ul. Mickiewicza 18

70-383 Szczecin, Polska

e-mail: anna.czaplinska@usz.edu.pl

Igor Kavetskyy, dr hab., prof. US, Uniwersytet Szczeciński, Wydział Nauk o Ziemi, Instytut Geografii Społeczno-Ekonomicznej i Gospodarki Przestrzennej, Zakład Geografii Społecznej i Organizacji Przestrzeni. Jego zainteresowania badawcze są związane z problematyką geografii społeczno-gospodarczej i politycznej, w tym zwłaszcza geografii wyborczej, geografii usług i marketingu terytorialnego.

Igor Kavetskyy, DSc, associate professor, University of Szczecin, Faculty of Geosciences, Institute of Socio-Economic Geography and Spatial Management, Human Geography and Spatial Organization Unit. The author's research interests concern the issues of socio-economic and political geography, especially electoral geography, geography of services and place marketing.

ORCID: 0000-0002-3516-5484

\section{Adres/Address:}

Uniwersytet Szczeciński

Wydział Nauk o Ziemi

Instytut Geografii Społeczno-Ekonomicznej i Gospodarki Przestrzennej

Zakład Geografii Społecznej i Organizacji Przestrzeni

ul. Mickiewicza 18

70-383 Szczecin, Polska

e-mail: igor.kavetskyy@usz.edu.pl 